\title{
Sporothrix brasiliensis produces the highest levels of oxidative stress in a murine model among the species of the Sporothrix schenckii complex
}

\author{
Débora Nunes Mario[1],[2], Larissa Finger Schaffer ${ }^{[3]}$, Luis Ricardo Peroza ${ }^{[3],}$ \\ Francielli Pantella Kunz de Jesus ${ }^{[3]}$, Laura Bedin Denardi ${ }^{[2]}$, Roselei Fachinetto $^{[3]}$ \\ and Sydney Hartz Alves ${ }^{[2]}$
}

[1]. Escola de Saúde, Imed, Passo Fundo, RS, Brasil. [2]. Programa de Pós-Graduação em Ciências Farmacêuticas, Universidade Federal de Santa Maria, Santa Maria, RS, Brasil. [3]. Programa de Pós-Graduação em Farmacologia, Universidade Federal de Santa Maria, Santa Maria, RS, Brasil.

\begin{abstract}
Introduction: We compared indicators of oxidative stress in the tissue of mice infected with strains from Sporothrix schenckii complex. Methods: Mice were inoculated with Sporothrix brasiliensis, Sporothrix schenckii sensu stricto, Sporothrix globosa, Sporothrix mexicana or Sporothrix albicans. The activity of catalase and glutathione were accessed in the liver and spleen. Results: Animals infected with $S$. brasiliensis exhibited splenomegaly and significant decrease in catalase activity, and protein and nonprotein thiol content compared to animals infected with the other species. Conclusions: Sporothrix brasiliensis exhibits higher pathogenicity compared to other species of the Sporothrix schenckii complex by increasing oxidative stress in animal tissue.
\end{abstract}

Key words: Sporotrichosis. Antioxidant enzymes. Oxidative stress.

The genus Sporothrix was recently reclassified as a complex including at least six species capable of causing sporotrichosis ${ }^{1}$. Subsequently, studies have been conducted in order to elucidate the different levels of virulence and pathogenicity demonstrated by each species ${ }^{2}$. According to previous studies, S. brasiliensis demonstrated the highest pathogenicity and virulence, while isolates of S. schenckii sensu stricto (s. str.) showed marked heterogeneity in the virulence profiles studied ${ }^{2,3}$. Sporotrichosis has a worldwide distribution and is the most common subcutaneous fungal infection in South America ${ }^{4}$. It is mainly acquired by traumatic inoculation of the subcutaneous tissue by the organism and can be disseminated to other parts of the body, particularly in immunocompromised patients ${ }^{4}$.

The ability of the fungal pathogen to cause disease depends on its survival in the host via evasion of the immune system, especially the antimicrobial mechanism of phagocytes ${ }^{5,6}$. Immune cell function is closely linked to the generation of reactive oxygen species (ROS) and is strongly influenced by the redox potential of the extracellular environment. Furthermore, the intracellular oxidant/antioxidant balance is an important determinant of the immune cell's activity; the antioxidant

Corresponding author: Dra. Débora Nunes Mario.

e-mail: debora_alves6@hotmail.com

Received 17 May 2016

Accepted 24 April 2017 level in immune cells plays a crucial role in protection against oxidative stress and preserving adequate function. Sporotrichosis causes tissue damage, which can lead to a state of oxidative stress, thereby reducing the immune response and enhancing pathogen survival in the host ${ }^{6}$.

It has been recognized that similar characteristics expressed by strains of S. brasiliensis and S. schenckii, but not by other species of the complex, result in these two species being the most pathogenic of the group. In the present study, we investigated differences in response to the oxidative stress induced by experimental infection with five species of the Sporothrix schenckii complex in a mouse model.

One strain each of the following species was included in the study: S. brasiliensis CBS 1330, S. schenckii s. str. Ss 02, S. globosa CBS 132922, S. mexicana CBS 120341, and $S$. albicans PG 03. The fungi were stored in slant cultures covered with sterile paraffin oil and subcultured on Sabouraud dextrose agar (SDA) plates at $30^{\circ} \mathrm{C}$ for 7 days.

Four-week-old BALB/c male mice (Animal House, Federal University of Santa Maria, Brazil) with a mean weight of $30 \mathrm{~g}$ were used. The mice were housed in standard boxes with adequate access to food and water in a room with controlled temperature $\left(22 \pm 2^{\circ} \mathrm{C}\right)$ and subjected to a $12 \mathrm{~h}$ light-dark cycle with lights on at 7:00am. The entire experiment was performed in accordance with the guidelines of the National Council for the Control of Animal Experimentation (CONCEA). 
A slice of the plate culture was inoculated into Sabouraud dextrose broth. The mycelia of the strains were grown at $25^{\circ} \mathrm{C}$ for 7 days using a rotary shaker at $150 \mathrm{rpm}$. The conidia were separated by gauze filtration and washed with sterile $0.05 \mathrm{M}$ phosphate-buffered saline (PBS), at a pH of 7.2. An inoculum size $\left(2 \times 10^{6} \mathrm{CFU} /\right.$ animal $)$ was ensured by cell counting in a Neubauer chamber and administered intraperitoneally in $0.2 \mathrm{~mL}$ of $\mathrm{PBS}^{7}$. Inoculum viability was verified by plating a volume of the fungal cell suspensions on SDA immediately after inoculation and determining the number of colony-forming units after 7 days of incubation at $30^{\circ} \mathrm{C}$ (minimum viability of $90 \%$ ). Five groups of 10 animals/group were each infected with a strain of the different species studied, and a sixth control group with 10 animals received only $0.2 \mathrm{~mL}$ of sterile saline. On the $14^{\text {th }}$ day after infection, all the animals were anesthetized with ketamine $(100 \mathrm{mg} / \mathrm{kg})$ and xylazine $(10 \mathrm{mg} / \mathrm{kg})$ and sacrificed by cervical dislocation. The liver and spleen were removed for $e x$ vivo analysis and the organs weighed prior to homogenization in Tris- $\mathrm{HCl}$ buffer $(\mathrm{pH} 7.4,10 \mathrm{mM})$ at a ratio of $1: 10 \mathrm{w} / \mathrm{v}$. The homogenates were centrifuged and the supernatants collected.

The activity of the antioxidant enzyme catalase in each of the organs was quantified by the spectrophotometric method of $\mathrm{Aebi}^{8}$, which measures the degradation of hydrogen peroxide $\left(\mathrm{H}_{2} \mathrm{O}_{2}\right)$ in the presence of tissue homogenate supernatant (phosphate buffer $\mathrm{pH} 7.0,25^{\circ} \mathrm{C}$ ) at $240 \mathrm{~nm}$. The enzymatic activity is expressed as $\mu \mathrm{mol} \mathrm{H}_{2} \mathrm{O}_{2} /(\min \cdot \mathrm{g}$ of tissue).

The total thiol content in each organ was measured by Ellman's assay'. For the determination of non-protein thiol, trichloroacetic acid (TCA) was added to the organ homogenate supernatants, the contents were centrifuged at 3000rpm for 10 minutes, and the deproteinated supernatants were used for the analysis. Ellman's reagent, 5,5'-dithiobis(2-nitrobenzoic acid) (DTNB) was added and the chromophore formed was measured spectrophotometrically at $412 \mathrm{~nm}$. The concentrations of protein and non-protein thiols were expressed as $\mu \mathrm{mol}$ protein thiol $/ \mathrm{g}$ tissue and non-protein thiol/g tissue, respectively.

Inter-group comparisons were carried out by analysis of variance [(ANOVA) one-way] followed by post-hoc Tukey's test, with the significance level set at 0.05 .

The analysis of the liver and spleen of the mice infected with $S$. brasiliensis showed significant decreases in catalase activity in the liver $(\mathrm{p}=0.0042)$, protein thiol content in the liver $(\mathrm{p}<0.0001)$, and non-protein thiol content in the spleen $(p<0.0001)$ (Figure 1). The liver weights showed no significant differences between the two groups. However, the mice infected with $S$. brasiliensis showed pronounced splenomegaly with significant increases in organ weight compared with either the control group or the mice infected with other species of Sporothrix $(\mathrm{p}<0.0001)$ (Figure 2). The other species also showed no significant differences compared with the control group in this regard.

The pathogenic mechanisms of Sporothrix are quite complex, showing intra and interspecies variability depending on the host immune response $\mathrm{s}^{5,10}$.

Comparative studies of virulence with species of the complex showed that the lesional mechanisms might be species specific,
S. brasiliensis being the most virulent species, followed by Sporothrix schenckii, Sporothrix globosa, Sporothrix mexicana, and Sporothrix pallida ${ }^{2}$. The authors found that $S$. brasiliensis showed a remarkable tropism for the brain, while for S. schenckii and $S$. globosa this tropism was lower.

In this study, the liver and kidney were the organs that showed greater vulnerability to oxidative stress caused by infection with Sporothrix, especially by S. brasiliensis.

Fernandes et al. observed a large heterogeneity in virulence profiles among different isolates of $S$. schenckii s. str. S. brasiliensis (CBS 132990) was the most virulent strain, leading to mortality within a short time of infection with a high fungal load'. In contrast, S. globosa (CBS 132922) was completely non-virulent with zero fungal load and survival of the animals at the end of the experiment ${ }^{3}$.

Some studies have investigated the protein secretion profile of Sporothrix spp. Fernandes et al. showed that Brazilian $S$. schenckii isolates express different proteins ${ }^{11}$. It was also observed that the humoral response profiles of mice infected with $S$. schenckii s. str., S. globosa, and S. brasiliensis were distinct. The most virulent isolates (including $S$. schenckii s. str., and $S$. brasiliensis isolates), had in common $60-\mathrm{kDa}$ and $110-\mathrm{kDa}$ molecules, suggesting that these antigens could be involved in virulence ${ }^{3}$.

Reactive oxygen species are used by the host's immune system to eliminate an infectious agent by causing irreversible damage to their cellular components and eventually cell death. Cells of the host immune system, such as macrophages and neutrophils, can generate an oxidative burst following phagocytosis of fungal pathogens ${ }^{5,12}$.

In the present study, we investigated catalase enzyme activity and levels of thiols (protein and non-protein), as these are markers that change rapidly in response to cellular oxidative stress. Catalase is an enzyme responsible for the degradation of the ROS hydrogen peroxide, which is highly toxic to the cell ${ }^{13}$. In the initial phase of an infection, the decrease in the levels of this enzyme may reflect an increase in the formation of hydrogen peroxide. The results presented indicate that this decrease occurred predominantly in the organs of animals infected with S. brasiliensis. Likewise, glutathione, a major cellular antioxidant also appears to be depleted by the antioxidation system of animals infected with $S$. brasiliensis as demonstrated by the significant reduction in the levels of protein and nonprotein thiols in the liver and spleen, respectively.

Sporothrix brasiliensis is more resistant to peroxide stress than $S$. schenckii, which might be expected as $S$. brasiliensis is normally associated with the zoonotic outbreaks seen in Brazil. It is thought to be adapted to felines from which it can infect human hosts ${ }^{14}$. Interestingly, a recent study that showed plant pathogens are less resistant to peroxide stress than human fungal pathogens supports the idea that the species of the Sporothrix schenckii complex will display different adaptation strategies, and this will influence the likely route of infection ${ }^{15}$. These differences can also affect the resulting pathogenicity of each species in humans. For example, S. brasiliensis is known to be a more virulent pathogen than $S$. schenckii, but the latter 
SPLEEN
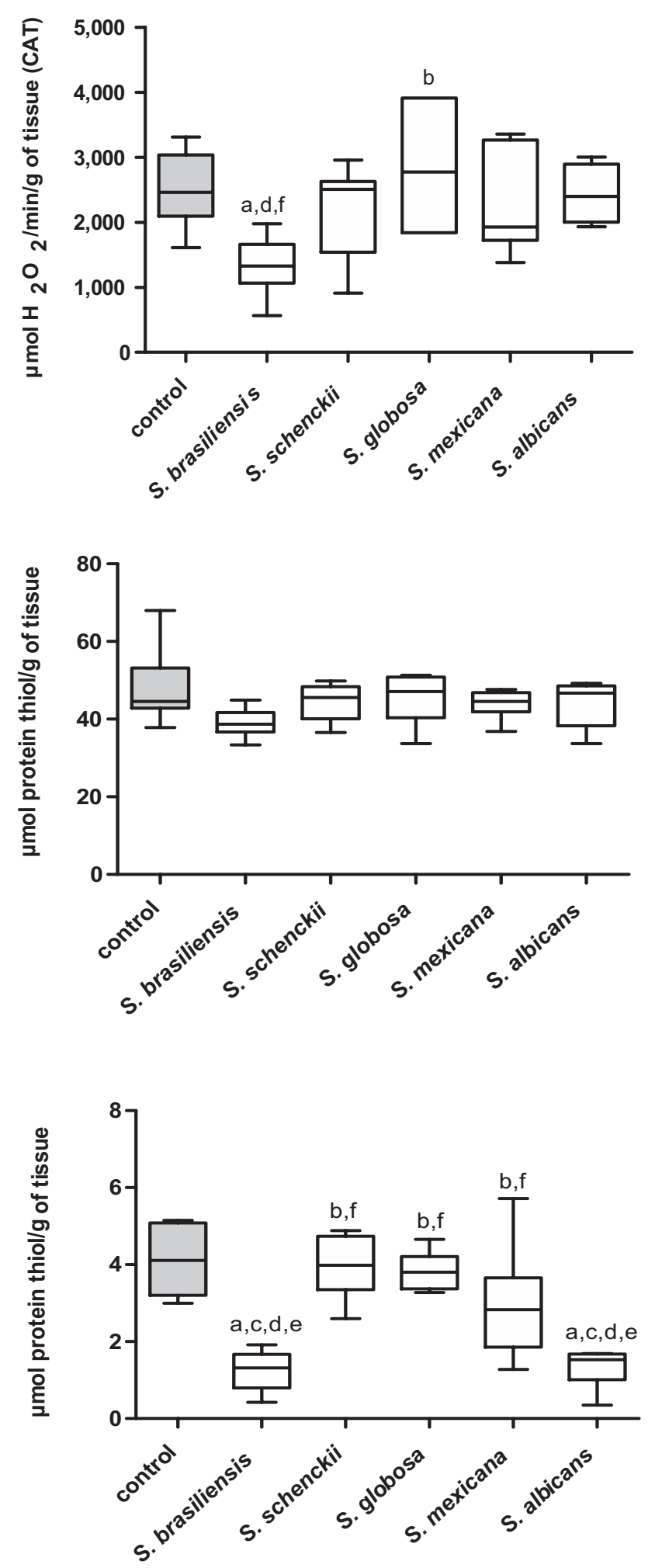

LIVER
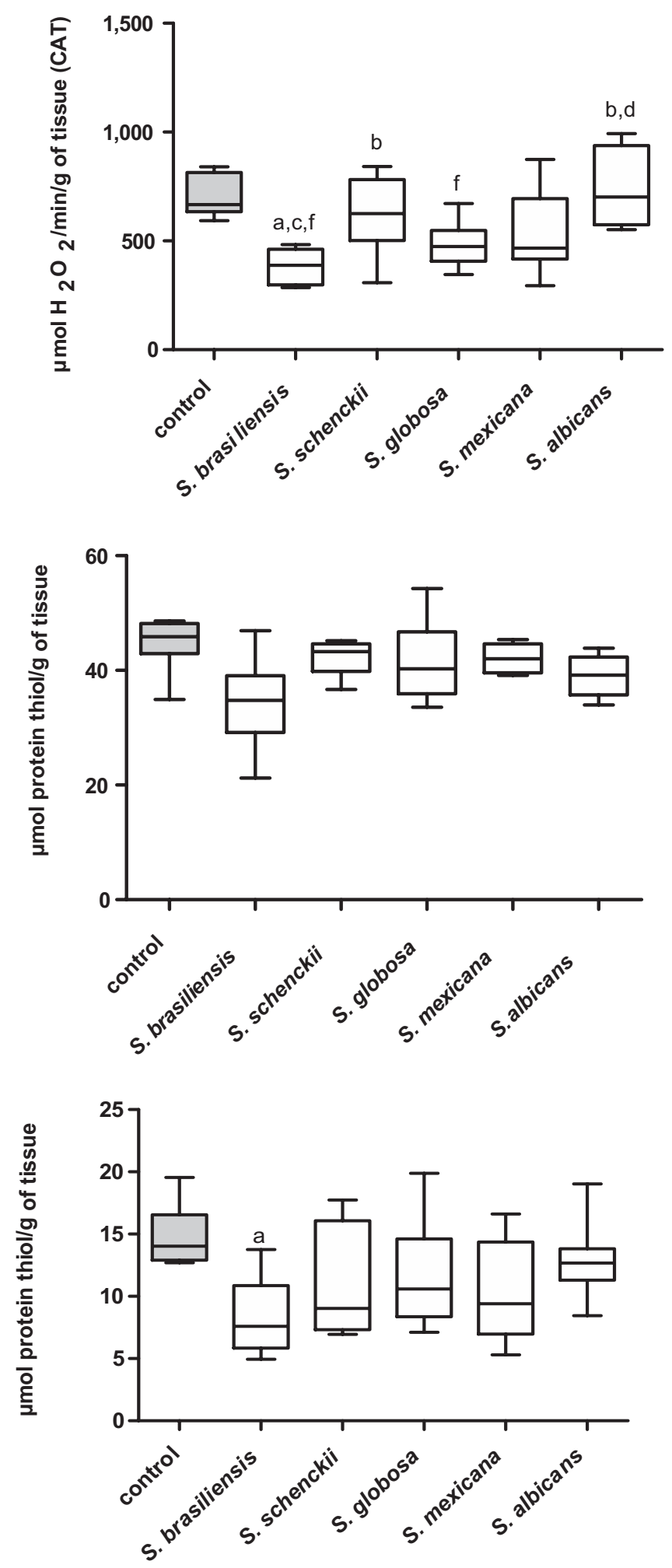

FIGURE 1 - Catalase activity and content of protein and non-protein thiol in the liver and spleen of animals infected with strains of the Sporothrix schenckii complex. ${ }^{\mathbf{a}}$ Control; ${ }^{\mathbf{b}}$ S. brasiliensis; ${ }^{\mathbf{c}}$ S. schenckii; ${ }^{\mathbf{d}}$ S. globosa; ${ }^{\mathbf{e}}$ S. mexicana; ${ }^{\mathbf{f}}$ S. albicans. S.: Sporothrix. 

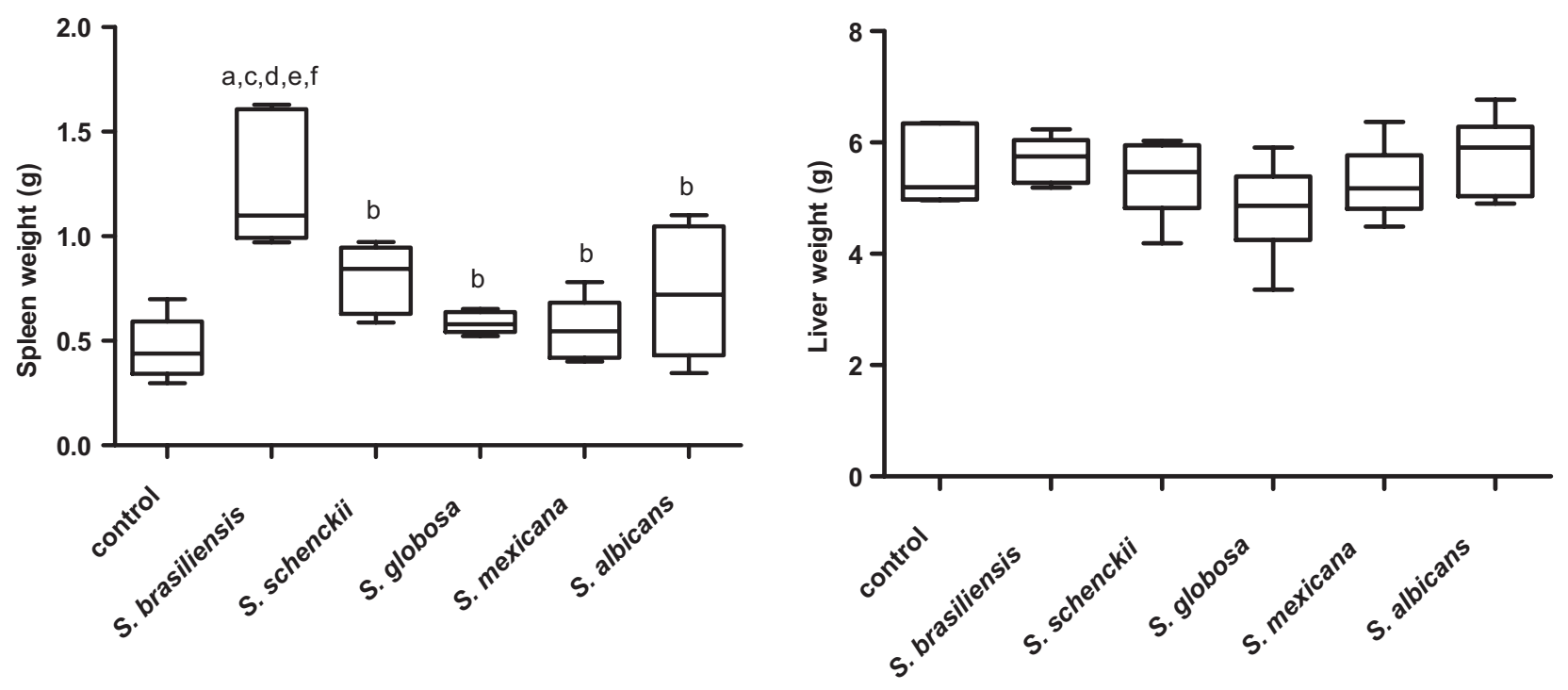

FIGURE 2 - Liver and spleen weight of animals infected with strains of the Sporothrix schenckii complex. ${ }^{\mathbf{a}}$ Control; ${ }^{\mathbf{b}}$ S. brasiliensis; ${ }^{\mathbf{c}}$ S. schenckii;

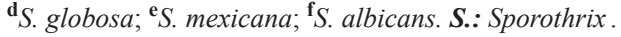

species is always involved in infections resulting from traumatic inoculation via contaminated vegetal debris and soil.

\section{Ethical considerations}

The study was also approved by the Ethics Committee on Animal Use of the Federal University of Santa Maria, Brazil, prior to the start of experimentation (approval number: 006/2014).

\section{Conflict of interest}

The authors have not conflicts of interest to declare.

\section{Financial support}

This study received funding from the Foundation for Research Support of the State of Rio Grande do Sul (FAPERGS).

\section{REFERENCES}

1. Marimon R., Cano J, Gené J, Sutton DA, Kawasaki M, Guarro J. Sporothrix brasiliensis, S. globosa, and S. mexicana, three new Sporothrix species of clinical interest. J Clin Microbiol. 2007;45(10):3198-206.

2. Arrillaga-Moncrieff I, Capilla J, Mayayio E, Marimon R, Mariné M, Gené J, et al. Different virulence levels of the species of Sporothrix in a murine model. Clin Microbiol Infect. 2009;15(7):651-5.

3. Fernandes GF, dos Santos PO, Rodrigues AM, Sasaki AA, Burger E, de Camargo ZP. Characterization of virulence profile, protein secretion and immunogenicity of different Sporothrix schenckii sensu stricto isolates compared with $S$. globosa and $S$. brasiliensis species. Virulence. 2013;4(3):241-9.

4. Kwon-Chung KJ, Bennett JE. Sporotrichosis. In: Kwon-Chung KJ, Bennett JE, editors. Medical Mycology. Philadelphia, USA: Lea \& Febiger; 1992. p. 707-29.
5. Carlos IZ, Sassá MF, Sgarbi DB, Placeres MP, Maia DG. Current research on the immune response to experimental sporotrichosis. Mycopathologia. 2009;168(1):1-10.

6. Kajiwara H, Saito M, Ohga S, Uenotsuchi T, Yoshida S. Impaired host defense against Sporothrix schenckii in mice with chronic granulomatous disease. Infect Immun. 2004;72(9):5073-9.

7. Fernandes KSS, Mathews HL, Lopes-Bezerra LM. Differences in virulence of Sporothrix schenckii conidia related to culture conditions and cell-wall components. J Med Microbiol. 1999;48(2):195-203.

8. Aebi H. Catalase in vitro. Method Enzymol. 1984;105:121-6.

9. Ellman GL. Tissue sulfhydryl groups. Archives Biochem Biophysic. 1959;82(1):70-7.

10. Oliveira DC, de Loreto ES, Mario DAN, Lopes PG, Neves LV, da Rocha MP, et al. Sporothrix schenckii complex: susceptibilities to combined antifungal agents and characterization of enzymatic profiles. Rev Inst Med Trop Sao Paulo. 2015;57(4):289-94.

11. Fernandes GF, Do Amaral CC, Sasaki A, Godoy PM, De Camargo ZP. Heterogeneity of proteins expressed by Brazilian Sporothrix schenckii isolates. Med Mycol. 2009;47(8):855-61.

12. Angelova MB, Pashova SB, Spasova BK, Vassilev SV, Slokoska LS. Oxidative stress response of filamentous fungi induced by hydrogen peroxide and paraquat. Mycol Res. 2005;109(2):150-8.

13. Chaudière J, Ferrari-Iliou R. Intracellular antioxidants: from chemical to biochemical mechanisms. Food Chem Toxicol. 1999;37(9-10):949-62.

14. Schubach A, Schubach TM, Barros MB, Wanke B. Cat-transmitted sporotrichosis, Rio de Janeiro, Brazil. Emerg Infect Dis. 2005;11(12):1952-4.

15. Ortega I, Felipe MSS, Vasconcelos ATR, Bezerra LML, Dantas AS. Peroxide sensing and signaling in the Sporothrix schenckii complex: an in silico analysis to uncover putative mechanisms regulating the Hog1 and AP-1 like signaling pathways. Med Mycol. 2015;53(1):51-9. 